\title{
Gender Imbalance in Teaching Profession and Learning Outcome in Mathematics in Primary Schools in Esan West Local Government Area of Edo State
}

DOI: https://doi.org/10.47175/rielsj.v2i1.203

\section{| Olusi Felix Ilori |}

Institute Of Education

Ambrose Alli University, Ekpoma

ikakumo.fio@gmail.com

\begin{abstract}
The study assessed the imbalances in teaching profession in both public and private Nursery and Primary Schools, Public Secondary schools in Esan West Local Government Area of Edo State to determine the percentage/ ratio of imbalance and its relationship to learning outcome in mathematics at the primary school level. The study employed the descriptive survey research design. The population of the study comprised of all the seventy public and private Nursery and Primary Schools and thirty two public Secondary Schools with six hundred and sixty teachers in Esan West Local Government Area of Edo State. The data generated were analysed using the chi-square statistics. The findings from the study revealed that there was significant gender imbalance in teaching profession in Esan West Local Government Area of Edo State. The worst hit is the public nursery and primary school with an imbalance percentage of $78.87 \%$ and $21.13 \%$ in favour of female teachers while the private schools have a percentage imbalance of $76.02 \%$ and $23.98 \%$ in favour of female teachers. The female pupils' performance in mathematics was better than that of the male pupils. The study revealed that at the secondary school the imbalance was significant at the junior secondary school level and milled at the senior secondary. The study recommended the immediate reversal of the trend of imbalance by employing more male teachers into the public and private nursery and primary schools. This will improve the academic achievement of male pupils in mathematics, hence achieving the best practice in Nigeria education.
\end{abstract}

KEYWORDS

Gender imbalance; Academic Output in Mathematics

\section{INTRODUCTION}

In an exercise of this nature so many approaches to determine trends and best practices in education as bedrock for national development in Africa would have been postulated. Some may look at this from the views points of an idealist, whose concern is the training of the mind and liken it to a drum that need to be filled to the bream and then learning is said to have taken place and support subjects like the art and social sciences. Or the realist who look at the learner as a complete being that needed to be guided to discover the world himself, anything he can see makes sense and can be learnt, the unseen to him does not exist. Or the pragmatist who believes in the evolving man that need tochange subject to situations at hand.To the pragmatist the man is like a machine a machine if he is useful make use of him and if not replace him. Or theexistentialists who take concern on recognising theworth of one's existence before his relevance giving respect to man as the creation of God before 
subjecting him to shame or disgrace of irrelevant. To white in her book education whatsoever approaches without faith in God is incomplete. To Blooms inher taxonomy, teachers efforts should be gears towards teaching and and assessing learners in the three areas to achieve best practices as cognitive, affective and psychomotor and to add White "faith in God" in balancing the best trendsin education to learners described as functional education that will developed the brain, attitude, skills and faith in God. This paper tends to look at other areas that potent serious implications to achieving best practices if not addressed as gender imbalance in teaching profession in Nigeria schools. So what is gender imbalance?

Gender imbalance simply means the presence of more number of a particular sex of humans be it male or female in a particular environment. In many public and private schools all over the local government area of Edo state Nigeria, shows that the number of female workforce has outnumbered the male. This development is occurring in both urban and rural areas of the state, and across both private and public owned schools. In very few schools you find one or two male teachers, while majority are all female teachers. Evidence abounds to show that there is more number of female workforces in developed nations of the world. It is a well known fact that today the United Kingdom, (UK) has more female than male teachers and this gender imbalance is currently getting worse and not better (Stanley, 2016). The Department for education school workforce statistic in 2015 showed that the number of male teachers working in UK had fallen for the fifth consecutive years in 2010. One in four (1:4) teachers was a man while in 2015 one in five (1:5). This development has been associated with educational system that have achieved or nearly achieved the Universal Basic Education Goals (UBEG), which has been a long standing phenomenon that characterised the education system of many countries in the west, see Table 1

Table 1. Female Teachers Percentage at the Regional level Global view.

\begin{tabular}{|l|l|l|l|l|l|}
\hline \multirow{2}{*}{ s/n } & Region & \multicolumn{3}{|l|}{ Teaching Staff Percentage Females } \\
\cline { 3 - 6 } & & \multicolumn{2}{l}{$\begin{array}{l}\text { Primary } \\
\text { Education }\end{array}$} & \multicolumn{2}{l}{$\begin{array}{l}\text { Secondary } \\
\text { Education }\end{array}$} \\
\cline { 3 - 6 } & & 1999 & 2007 & 1999 & 2007 \\
\hline 1 & Arab States & 52 & 59 & 49 & 51 \\
\hline 2 & Central and Eastern Europe & 82 & 80 & 72 & 74 \\
\hline 3 & Central Asia & 84 & 86 & 65 & 69 \\
\hline 4 & East Asia and the Pacific & 55 & 60 & 46 & 48 \\
\hline 5 & Pacific & 71 & 75 & 57 & 56 \\
\hline 6 & Latin America and the Caribbean & 76 & 78 & 64 & 60 \\
\hline 7 & North America and West Europe & 81 & 85 & 56 & 61 \\
\hline 8 & South West Asia & 35 & 45 & 35 & 36 \\
\hline 9 & Sub Sahara Africa & 43 & 44 & 31 & 30 \\
\hline
\end{tabular}

Source; (UNESCO, 2011)

From table 1 above, only in South Asia, Sub Sahara Africa and the Arab State in 1999 and 2007 both at primary and secondary schools that recorded gender imbalance in favour of female less than 50\%.Learning outcomes revealed in the academic achievement of students differs across sex and location several studies that of Dee (2006) had noted that boys do better in the classes taught by men, while girls are more likely to thrive in classes taught by women. However, this result corroborates with that of Tarig \& Ali-Almad (2012) study which revealed that females students achieved better result in mathematics than male. 


\section{Statement of the Problem}

The increase in number of female teachers in our primary schools has come to stay. The academic and moral implications of this imbalance can only be revealed over time. This development has been associated with countries achieving universal basic education goals of the west. According to the study of Mohammed, Khair, and Khairani (2012) level of students achievements in mathematics at the elementary education in Yemen used a sample of 200 male and female students chosen from eight government schools; a mathematics test which composed of seventy five items that covered geometrical arithmetic operations as well as the equation and inequalities were administered. The result showed that the females tend to achieve better result in mathematics than the males, with percentage $\mathrm{Z}$ value difference for male and female as 20.50 and 43.5 with $\mathrm{Z}$ value of 4.79 at $\mathrm{p}<0.050$.

In Elsheiky (2010) Trend in International Mathematics and Science Study (TIMSS) result of mathematics achievement of Saudi Arabia grade 8 students the result of data analysed showed that achievement in mathematic was strongly associated with gender difference and it revealed that female achievement was significantly upper than that of the male. Similarly, Laucelot \& Gibb (2010) study investigated gender differences in performance on the mathematics components on the standard 3 national assessment in Trinidad and Tobago, to determine whether there was a relationship between attitudinal differences regarding mathematics and students belief in their mathematical abilities, and students' gender classification. Results indicated that girls performed better than boys on all categories and all skill areas. Similarly, Wo \& Lewis (2007) investigation of 5-14 years old students progress in mathematics attainment in England indicated that in the early years of schooling, individual differences in mathematics attainment are difficult to establish. In extending the discuss, Neville \& Croizet (2007) in a study of 7-8 years old conducted in France, found that when gender identity is salient girls perform better than boys on easy problems. On the other hand, boys' performance on mathematics was not affected by gender identity they were not subject to stereotype threat that made negative assumption about their mathematics ability and so they performed better on the more difficult problems. The probe of this study therefore is to determine the percentage gender imbalance in teaching profession in public and private nursery primary and secondary schools in Esan west local government area, to assess the implication of this imbalance on the academic achievement of pupils in mathematics in public and private nursery primary schools in Esan west local government area of Edo State.

\section{Purpose of the Study}

The study among other things determined the percentage level of imbalance in teaching profession in public and private nursery primary and secondary schools in Esan west local government area of Edo State Nigeria, verify the implication of this imbalance on the academic achievement of pupil

\section{Research Questions}

a. What is the percentage difference of gender imbalance in teaching profession in public and private nursery primary and secondary schools in Esan West Local Government Area of Edo State?

b. What is the difference between the percentage level of gender imbalance of teacher in urban and rural school in the study area?

c. Does any difference exist between gender imbalance of teachers in public and private nursery, primary and secondary schools in the study area? 
d. Does gender imbalance of teacher affects the academic achievement of students in mathematics in the study area?

e. Does any difference exist between gender imbalances of teachers in public secondary schools in the study area?

\section{Research Hypothesis}

1. The percentage differences of gender imbalance in teaching profession in Esan west Local government area of Edo State is not significant.

2. There is no significant difference between the level of gender imbalance of teachers in urban and rural nursery, primary and secondary schools.

3. There is no significant difference between gender imbalance of teachers in public and private nursery, primary and secondary schools in the study area

4. The differences in gender imbalance in teaching profession in Esan west Council of Edo State does not significantly affects the academic achievement of students in mathematics in the study area.

\section{RESEARCH METHODS}

The study employed the descriptive survey research design. A sample of seventy schools made up of forty five public and twenty five private nursery and primary schools and sixteen public Secondary Schools (JSS \& SSS) were used. The instrument for data collections were records of staff and academic achievement of pupils and students their various examinations in mathematics. The data generated were analysed using percentage and chi-square to determine the statistic significance differences.

\section{RESULTS AND DISCUSSION}

Ho1. The percentage differences of gender imbalance in teaching profession in Nursery and primary schools in Esan West Local government Area of Edo State is not significance.

Table 2. Percentage of imbalance in teaching profession in Esan west nursery and primary schools

\begin{tabular}{|l|l|l|l|l|l|}
\hline \multicolumn{2}{|c|}{ Teachers } & \multirow{2}{*}{ Total } & $\dot{\mathbf{x}}$ & \multirow{2}{*}{ P. Value } & \multirow{2}{*}{ Remarks } \\
\cline { 1 - 5 } Male & Female & & & & \\
\hline $145(22.87 \%)$ & $489(77.13 \%)$ & 634 & 186 & 3.87 & significant \\
\hline
\end{tabular}

Source; field study

From Table 2 above, out of a total of 634 teachers in the public primary schools in Esan West Local Government Area of Edo State, 145 representing 22.875 are males while 489 representing $77.13 \%$ are females. The chi-square calculated comparing the differences between these results, showed a value of 186.65 as against the $p$ value of 3.87 . This result shows that there was significant gender imbalance in teaching profession. This result is supported by various research studies that of UNESCO (2011) and Stanley (2016).

Table 3. Percentage Gender imbalance of Teachers in Urban and Rural Areas

\begin{tabular}{|c|c|c|c|c|c|c|c|}
\hline Sex & Urban schools & $\mathbf{D}$ & Rural schools & D & $\mathbf{X}$ & $\mathbf{P}$ & Remark \\
\hline Male & $82(17.83 \%)$ & \multirow[b]{2}{*}{$64.39 \%$} & $63(35.80 \%)$ & \multirow[b]{2}{*}{$28.40 \%$} & \multirow[b]{2}{*}{13.93} & \multirow[b]{2}{*}{3.87} & \multirow[b]{2}{*}{ significant } \\
\hline Female & $378(82.17 \%)$ & & $111(64.20 \%)$ & & & & \\
\hline
\end{tabular}

Source; field study 
From Table 3 above the number of male teachers in urban primary schools were 82 representing $17.83 \%$. The difference between the male and female teachers at the urban schools is $64.39 \%$. The number of male teachers in the rural schools was 63 representing $35.80 \%$ while the female teachers at the rural schools are 111 representing $64.20 \%$. The difference between the urban and rural was $28.20 \%$. The chi-square calculated to determine the statistical differences showed a value of 13.93 as against the p value 3.87 . The result showed that female teachers are more in both urban and rural schools though the percentage of female teachers is more in urban schools than the rural schools.

Table 4. Percentage gender imbalance between public and private school

\begin{tabular}{|c|c|c|c|c|c|c|c|}
\hline Sex & Public schools & D & Private Schools & D & $\mathbf{X}$ & $\mathbf{P}$ & Remark \\
\hline Male & $145(22.80)$ & \multirow[b]{2}{*}{$54.40 \%$} & $96(33.54 \%)$ & \multirow[b]{2}{*}{$32.86 \%$} & \multirow[b]{2}{*}{4.93} & \multirow[b]{2}{*}{3.87} & \multirow[b]{2}{*}{ significant } \\
\hline Female & $491(77.20)$ & & $190(66.43 \%)$ & & & & \\
\hline
\end{tabular}

Source; field study

From table 4 above the study revealed that the male teachers in public schools were 145 representing $22.80 \%$ while the female in public school were 491 representing $77.20 \%$ the male teachers in private primary and nursery schools in were 96 representing $33.57 \%$ while female teachers were 190 representing $66.43 \%$ the differences revealed a percentage of 32.86. When the imbalance between the private and public schools were compared statistically a chi-square value of 4.93 was obtained as against $p$ value of 3.87 . This result is confirmed that there was significant gender imbalance between private and public schools, the public schools having the highest imbalance

Table 5. Percentage differences in Gender imbalance and Academic Achievement in Mathematics at the public primary schools

\begin{tabular}{|c|c|c|c|c|c|}
\hline \multirow[b]{2}{*}{ Variable } & \multicolumn{2}{|l|}{ Sex } & $\mathbf{X}$ & P value & Remarks \\
\hline & Male & Female & \multirow{4}{*}{5.00} & \multirow{4}{*}{3.87} & \multirow{4}{*}{ Significant } \\
\hline Teachers & $145(22.87 \%)$ & $489(77.13 \%)$ & & & \\
\hline Students sample & 1905 & 2361 & & & \\
\hline $\begin{array}{l}\text { Number of students who } \\
\text { scored above } 50 \% \text { in Maths }\end{array}$ & $901(47 \%)$ & $1684(71.32)$ & & & \\
\hline
\end{tabular}

Source; field study

From table 5 above the percentage differences in gender imbalance between male and female teachers and the academic achievement of pupils in public and private primary schools was determined the differences in teacher imbalance of $77.13 \%$ and academic achievement of pupils in mathematics . out of 1905 male pupils 901 representing 47\% Pupils Scored 50\% and above while out of 2361 female 1684 representing $71.32 \%$ scored $50 \%$ and above. The differences showed a chi-square value of 5 against $p$ value of 3.87 . This result confirms that gender imbalance significantly influences achievement in mathematics in favour of the female pupils. It also confirms the position of Laucelot \& Gibbs (2010) Wo and Lewis (2007) and Newville and Croizet (2007).

The study of Ajai and Imoko (2015) also noted that female students outperformed their male counterpart (both post-test and retention) though the difference is not statically significant. The result is also consistent with Hydea and Mertzb (2009) which says girls have reached parity with boys in mathematics achievement they noted that this is an indication that girls can do better than boys in task that require complex problem, such as PBL. This position also agrees with narrow achievement reported in the United state of America by 
Perie, Morgan \& luktus (2005) and Australia by Forgasz, Leeler\& Vale (2006) however which was in variance with Ogunkunle (2007) in Nigeria where part of the finding established significant difference in favour of males and another in favour of females. But the word of Dee (2006) which noted that girls have better educational outcomes when taught by women and boys are better off when taught by men cannot be overlooked.

Table 6. Percentage Gender imbalance in Teaching Profession in Public Secondary Schools

\begin{tabular}{|l|l|l|l|l|l|l|l|}
\hline \multirow{2}{*}{$\begin{array}{l}\text { Nos. of } \\
\text { schools }\end{array}$} & \multirow{2}{*}{ Level } & \multicolumn{2}{|c|}{ Sex } & \multirow{2}{*}{$\mathbf{X}^{2}$ sex } & \multirow{2}{*}{$\mathbf{X}^{\mathbf{2}}$ level } & P value & Remark \\
\cline { 3 - 4 } & & Male & Female & & \multirow{2}{*}{12.956} & \multirow{2}{*}{3.87} & \multirow{2}{*}{ Significant } \\
\hline 16 & JSS & $33(35.10)$ & $61(64.89 \%)$ & 8.34 & & & \\
\hline 16 & SSS & $68(60.18)$ & $45(39.82)$ & 4.68 & & \\
\hline
\end{tabular}

Source Field study

Table 6 above on the gender imbalance of teachers in teaching in public secondary schools, the result showed that male teachers in Junior Secondary Schools (JSS) were 33 representing $35.10 \%$ while the female were 61 representing $64.89 \%$. the differences in imbalances is 8.34 in favour of female while at the Senior Secondary School (SSS) the imbalances showed that the male teachers were 68 representing $60.18 \%$ and females 45 representing 39.82\%. The differences at Senior Secondary Level was also significant but in favour of the male teachers. The difference between JSS and SSS was carried out and revealed a chi-square of 12.956 as against 3.87.p value. This result confirms that the gender imbalance was significantly higher at the JSS in favour of female teachers.

\section{Summary}

This study revealed that there was significant gender imbalance in teaching profession in public and private urban and rural schools in Esan West local government area ofEdo State. This imbalances was also seen to be responsible for better achievement in mathematics in favour of the female pupils. At the Secondary School Level the Junior Secondary showed significant gender imbalance while the Senior Secondary Schools showed an imbalance in favour of male teachers. The study confirm that at the Primary School Level the female teachers are dominant

\section{CONCLUSION}

The training of pupils at the Primary School Level which form the foundation of education is left in the hands of the female sex. The implication can be inferred from the challenges of single parenting.

Certificates are supposed to be issued to pupils worthy in character and learning its obvious that the lopsidedness of teachers in favour of female can potent serious implications.

\section{Recommendations}

1. The study recommend the improvement of conditions of service and remuneration to encourage more male into the teaching at the lower level which is the foundation

2. To carry over the challenge of single parenting in schools, more male should be employed into teaching profession.

3. To reduce gender imbalance disparity in urban and rural areas, government should encourage improves conditions in rural areas to attract urban rural drift. 
4. Gender imbalance is evolving it and has eaten up the primary school level and junior secondary schools level. something should be done quickly before it gets to senior secondary schools.

5. Mathematics, the language of numbers, is the mother of sciences all science subjects required a credit grade in it before admission. If the male students are falling out in performance there is a serious danger for the future men driven careers. Effort should be concerted by government to address this before the worst happens

The influence of stereotypes on achievement is taking its toll on themale students. The female teacher will need to encourage male students to overcome for better achievements.

\section{REFERENCES}

Dee, T.S. (2006). The why Chromosome: How a Teacher Gender affects Boys and Girls Retrieved from www.educationnex.org, $6^{\text {th }}$ Feb 2019

Eishelkyt, S. (2010). Trend in international mathematics and science study (TIMSS) result of mathematics achievement of Saudi Arabia Grade 8 students' paper presented at the scientific research strategies conference the Islamic word Universities Malaysia

Hydea, J.S \& Mertzb, J.E. (2009). Gender, culture and mathematics performance retrieved from http;/tctvideomadeson.com/uw/gender

Laucelot, B \& Gibb Y.K. (2010). Gender Differences in mathematic performance in Trinidad and Tobago: Examining affective factors international electronic. Journal of Mathematics Education 5(3) 113-129

Neville, E \& Groceet .I. (2007). Can salience of gender identity impair mathematics performance among 7-8 years old girls? The moderating role of task difficulty;. European Journal of Psychology of Education 22 307-326

Ogunkunle, L.A (2007). Effect of gender on mathematics achievement of students in constructivist and non constructivist group in secondary schools. Abacus journal of Mathematics in Nigeria 32(1) 41-50

Perie, Moran, R \&Lukus A.D (2005). NAEP 2004 trends in academic progress three decade of students reading mathematics Washington DC national centre for statistics.

Stanley, J. (2016). Teaching feminization, profession competence; role models gender growing in teaching profession

Tarig, A. \& Ali, A. (2012). Sex differences in mathematics ability; facts or artifact science 210, 1262-1264 Journal of Education and Practice

United Nation Education Scientific Organization. (2011). Women and the Teaching Profession; exploring the feminization debate

Wo, W.J \& Lewis, S. (2007). Mathematics progressive 5-14 plateau curriculum / age and test years effects research in mathematics education 9(1) 127-142 